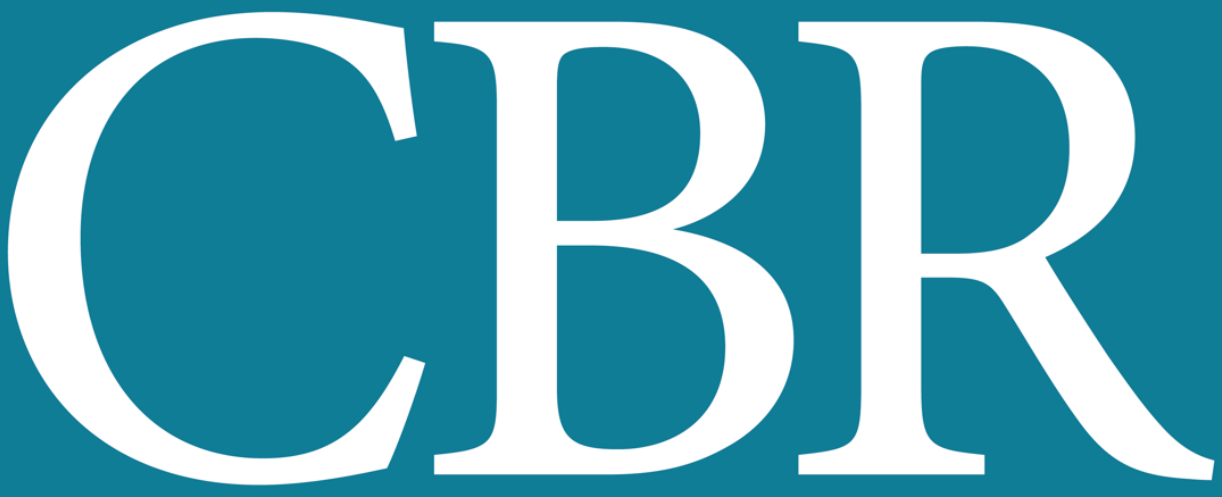

INTERNATIONAL JOURNAL OF CANCER AND BIOMEDICAL RESEARCH

https://jcbr.journals.ekb.eg

Editor-in-chief

Prof. Mohamed Labib Salem, PhD

Adipose-derived mesenchymal stem cells ameliorate the damages induced by arsenic trioxide in the testis of rats

Mona Mohamed Atia 


\section{Welcome letter from Editor-in-Chief}

Welcome to the Int J Cancer and Biomedical Research (IJCBR)!

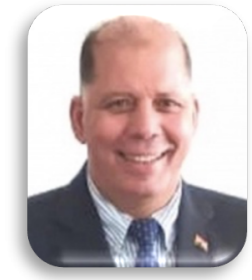

It is with great pleasure that I write this editorial to welcome you to the IJCBR. This journal provides a platform for publication of original and reviews research articles, short communications, letter to editor, thesis abstract, conference report, and case studies. These types of publication are directed at the interface of the fields of cancer and biomedical research.

The IJCBR relies on a distinguished expert of the Advisory and Editorial Board Members from the top international league covering in depth the related topics. They timely review all manuscripts and maintain highest standards of quality and scientific methodology and ethical concepts. Meanwhile, we take all possible means to keep the time of the publication process as short as possible.

I take this chance to welcome your contributions to the IJCBR and have every expectation that it will soon become one of the most respected journals in both the fields of cancer and biomedical research.

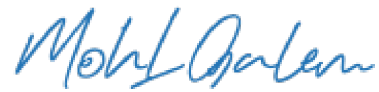

Mohamed L. Salem,

Editor in Chief 


\title{
Adipose-derived mesenchymal stem cells ameliorate the damages induced by arsenic trioxide in the testis of rats
}

\author{
Mona Mohamed Atia \\ Department of Zoology, Faculty of Science, Assiut University, Assiut, Egypt
}

\begin{abstract}
III ABSTRACT

Background: Arsenic trioxide is an element present everywhere in the environment. Aim: The current investigation planned to explain the remedial impacts of adipose mesenchymal stem cells (AD-MSCs) of rats against harmful impacts of Arsenic trioxide $\left(\mathrm{As}_{2} \mathrm{O}_{3}\right.$; As III) on the testis of rats. Materials and Methods: Sixty male rats were divided into six groups: Group (1): served as the control without any treatments. Group (2): received a daily oral dose of $\mathrm{HCL}(0.5 \mathrm{mg} / \mathrm{kg}$ b.w). Experimental groups ( 3 and 4 ) received a low dose $(3 \mathrm{mg} / \mathrm{kg} \mathrm{b.w}$ ) of As III and groups $(5,6)$ received a high dose $(15 \mathrm{mg} / \mathrm{kg}$ b.w) of As III. The rats were sacrificed after 15 days in groups $(3,5)$. Groups $(4,6)$ were injected with $\left(0.6 \times 10^{6}\right)$ AD-MSCs $/ 0.5 \mathrm{ml}$ PBS immediately after 15 days of oral doses of As III in low and high dose then sacrificed 7 days after MSCs injection. Results: The results indicated that AD-MSCs decreased the levels of p53 and Bax and increased the level of Bcl2. Additionally, treatment with AD-MSCs rescued the toxicity of low and high doses (L \&H) As III induced change in TNF- $\alpha$, IL-6, and IL-10 levels. In addition, As III L \&H + AD-MSCs administration resulted in the gradual elevation of CD44 mRNA compared to control untreated mice. low and high doses of As III prompted histopathological damages in testis were they mostly turned around by treatment of AD-MSCs. Conclusion: The present results demonstrate that $A D-M S C s$ got from the adipose tissue of rats can be a powerful treatment against harmfulness induced by As III in testis.
\end{abstract}

Keywords: Arsenic trioxide, Apoptosis, Adipose mesenchymal stem cells, Cytokines, testis injury.

\section{ARTICLE INFO}

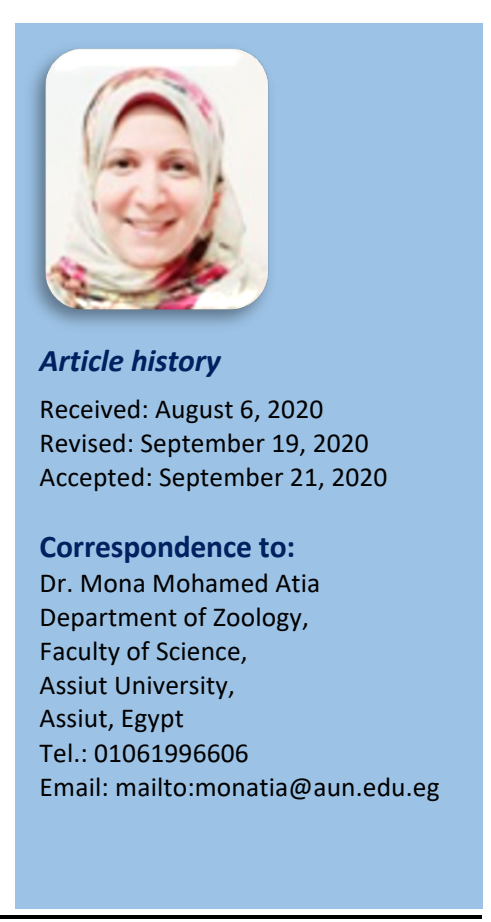

\section{INTRODUCTION}

Heavy metals like Arsenic starts cytotoxicity by presenting oxidative stress (Liu et al., 2003). Oxidative stress emerges when responsive oxygen species by Arsenic occurs in both natural and inorganic structures. In nature yet inorganic types of arsenic [As III and As V] are considered to be a likely danger to the environment, humans and other organisms because of their cancer-causing and different bad impacts (Singh and Pant, 2004). The attributes of intense arsenic poisonousness incorporates harmful effects on the gastrointestinal (Hughes, 2002), neoplastic changes of the skin and respiratory tract, haematopoietic, cardiovascular, anxious, hepatic, endocrine and kidney (Wang et al., 2006). Different experiments have indicated severe gonadal harm in different animals during spermatogenesis following exposure to heavy metals (Mandal and Das, 2012; Mahajan et al., 2018). In addition, arsenic is a notable human cancer-causing agent (Balakumar et al., 2010).

It has been reported that inducing oxidative stress by arsenic has a toxic effect on the testis of the mice finally leads to a gradual decrease in the spermatic tube diameter (Sanghamitra et al., 2008 and Mehrzadi et al., 2018). Also arsenic induces distortions in the male reproductive system and spermatotoxicity in many animals (Sarkar et al., 2003; Pant et al., 2004 and Chang et al., 2007). Likewise, arsenic may actuate hypogonadism through the decline of testosterone and apoptosis (Shen et al., 2013 and Zubair et al., 2017). Arsenic trioxide has proficiently prompted apoptosis in the cancer cells in vitro by the exposure of some malignant cells to As III produces reactive oxygen species and decrease of p53 level using both caspase- 
depended and non-depended pathways (YoonJae Kim et al., 2011).

Bone marrow has adult stem cells known as mesenchymal stem cells (MSCs), which are characterized as pluripotent cells. These cells can differentiate into multiple mesodermal cells. MSCs must express CD73, CD105 and CD90, and no expression of CD45, CD34, CD14 or CD19 (Dominici et al., 2006 and Malihezaman Monsefi et al., 2013). MSCs are stromal cells that can self-reestablish and separate into mesodermal and nonmesodermal cell ancestries, including osteocytes, adipocytes, chondrocytes, myocytes, cardiomyocytes, fibroblasts, myofibroblasts, epithelial cells, and neurons (Millman and Pagliuca, 2017). MSCs has unique features, their transplantation can improve different diseases. In rat stroke models, after 7 days of bloodstream restriction to the brain, MSCs injection leads to restoration of blood flow (Jung et al., 2011). MSCs secreted enormous amounts of bioactive components that are both immunomodulatory and trophic. The trophic action activated mitosis of tissue progenitor cells (Melanie et al., 2012). Likewise, MSCs can improve the germinal epithelial potential in testicular seminiferous tubules in male rats (Malihezaman Monsefi et al., 2013).

Effective utilization of MSCs in a few animals models improves diverse organ harmfulness (Lim et al., 2016 and Wang et al., 2017) evoked the direction of the current examination to assess AD-MSCs against testicular harm prompted by As III L\&H doses. MSCs separated from adipose tissue has more proliferative limit than BM-MSCs (Zuk, 2010). As of late, the researchers began to look for another source for MSCs instead of the bone marrow because of MSCs from the latter yield low cell number upon harvest (Zuk et al., 2002). Adipose tissuederived mesenchymal stem cells (AD-MSCs) are gotten from the mesenchyme which contains strong stroma that is easily disengaged. In this manner, it is believed that adipose tissue may represent a rich source of stem cells that could have effects on many fields (Atalla et al., 2018).

Emerging proof has built up that MSCs and ADMSCs can repair and recover tissues and the valuable impacts of MSCs transplantation to the various organs are being tried clinically for relieving different sicknesses (Monsefi et al., 2013). MSC can rectify tissues, through cytokines, apoptosis inducers, autocrine, paracrine, juxtacrine factor. They can also be hereditarily built to create antitumor particles for example interferon $\beta$ (INF $\beta$ ) and TNF-related apoptosis-inducing ligand (TRAIL) (Li $Z$ et al, 2015; Metwall et al., 2017 and Serhal et al., 2019). Along these lines, the current investigation intended to show the conceivable restorative impact of AD-MSCs against arsenicinduced testicular toxicity in male rats.

\section{MATERIALS AND METHODS}

Drug and animals

As III from (Sigma-Aldrich, St. USA). A stock solution of Arsenic trioxide was prepared by dissolving it into $0.12 \mathrm{~N} \mathrm{HCL}(0.5 \mathrm{mg} / \mathrm{kg} \mathrm{b.w})$. Two doses of Arsenic trioxide ( $3 \& 15 \mathrm{mg} / \mathrm{kg}$ ) were used in the current work. Sixty adult male Wistar rats weighting $210 \pm 50 \mathrm{~g}$ were purchased from Assiut University Joint Animal Breeding Unit. Rats were kept in $23 \pm 2{ }^{\circ} \mathrm{C}$ and a lighting cycle of 12 hours light /dark. The procedures of the experiment were conducted in strict compliance with ethics prepared by INSA and (WHO/UNESCO).

\section{Experimental design}

Sixty male rats were divided into six groups, each group consists of 10 rats: Group (1): served as a control without any treatments. Group (2): received a daily oral dose of $0.12 \mathrm{~N} \mathrm{HCL}(0.5$ $\mathrm{mg} / \mathrm{kg} \mathrm{b.w})$. Experimental groups $(3,4)$ received a low dose $(3 \mathrm{mg} / \mathrm{kg} \mathrm{b.w}$ ) of As III. Experimental groups $(5,6)$ received a high dose $(15 \mathrm{mg} / \mathrm{kg}$ b.w) of As III. The rats were sacrificed after 15 days in groups $(3,5)$. In groups $(4,6)$ each rat was injected with $\left(0.6 \times 10^{6}\right)$ AD-MSCs / $0.5 \mathrm{ml}$ PBS via caudal vein immediately after 15 days of oral doses of As III then they were sacrificed 7 days after AD-MSCs transplantation.

\section{Methods \\ Isolation of AD-MSCs from rats}

AD-MSCs were isolated from the visceral fats of adult rats. Fats were taken and cut into small pieces at a range of 1-3 $\mathrm{mm}$. To remove the remaining blood from the adipose tissues, the latter was washed three times with sterile phosphate buffer solution. Adipose tissue pieces were enzymatically digested with $0.25 \%$ 
Collagenase type II in PBS with 20\% FBS for 4560 minutes at $37^{\circ} \mathrm{C}$ with shaking every $15 \mathrm{~min}$. The collagenase activity was stopped by $5 \mathrm{ml}$ of fetal bovine serum. After that centrifugation for $10 \mathrm{~min}\left(1800 \mathrm{rpm}, 25^{\circ} \mathrm{C}\right)$, the supernatant was discarded and pellets were suspended in $12 \mathrm{ml}$ of DMEM culture medium. The suspension Filtrated through a cell strainer $(40 \mu \mathrm{m})$ into a fresh $50 \mathrm{ml}$ falcon tube. Then transferred the cell suspension into a culture flask and incubated at $37^{\circ} \mathrm{C}$ with $5 \% \mathrm{Co}$. The medium was changed three times a week, and The cells were grown Approximately for 15 days until almost confluency $80 \% .3^{\text {rd }}$ passages of MSCs were suitable for transplantation (Harsan et al., 2015).

\section{Morphological Characterization of AD- MSCs}

AD-MSCs were observed under an inverted microscope, at passage 1 they have had a fibroblast-like morphology.

\section{Analysis of Cell Surface Markers of AD-MSCs by flow cytometry}

After the third passage, the undifferentiated AD-MSCs were subjected to flow cytometer analysis to detect the following antigens: CD105, 44 and 14 by using monoclonal antibodies specific for each antigen. Adherent cells were adjusted to trypsinization with $0.25 \%$ trypsin/ EDTA. $1 \times 10^{5}$ cells $/ \mathrm{ml}$ were then fixed for $30 \mathrm{~min}$ in ice-cold $2 \%$ formaldehyde. The fixed cells were washed in flow cytometry buffer then incubated for $30 \mathrm{~min}$ in the buffer of flow cytometry containing fluorescein isothiocyanate-conjugated monoclonal antibodies: CD105, 44 and CD14 IgG (Beckman coulter, USA) at 4 - $C$ in the dark. Then $2 \mathrm{ml}$ of PBS solution containing $2 \%$ FBS were added to each tube of monoclonal treated cells. Cells were centrifuged and re-suspended in $0.5 \mathrm{ml}$ of PBS containing $2 \%$ FBS solution. CYTOMICS FC 500 Flow Cytometer (Beckman Coulter, FL, USA) was used for Cell analysis with CXP Software version 2.2. Flow cytometry analysis of $A D$ MSCs revealed positive expression of CD105, 44 and negative expression of CD14.

\section{Western blot analysis}

For AD-MSCs characterization, the third passaged AD-MSCs were harvested using trypsin/EDTA digestion and suspended at a concentration of $0.6 \times 10^{6}$ cells $/ 100 \mu \mathrm{l}$ in PBS. Cells were lysed and equal protein amounts were subjected to SDS PAGE electrophoresis and then the protein band was transferred onto a nitrocellulose membrane. Monoclonal IgG antibodies against $\mathrm{cd} 105,44$ and 14 were applied and then secondary anti-mouse IgG HRP conjugated antibody was applied. Immunoreactive bands were visualized by enhanced chemoluminescence substance. Actin was used as an internal control for protein equal loading. CD 105 and CD 44 are positive markers for stem cell and CD 14 is a positive marker for leukocytes but a negative marker for stem cell. Western blot analysis for the evaluation of P53, Bax and BCL2 levels in testis after different treatments were carried out in a similarly as described above except for some modifications. samples of testis were homogenized in RIPA Lysis buffer (Nonidet-P40 1\%, TritonX-100 1\%, Na dioxycholate $0.5 \%, \mathrm{NaCl} 150 \mathrm{mM}$, EDTA 5 mM, EGTA 10 mM, Tris-HCl 50 mM., PMSF 1 $\mathrm{mM}$, protease inhibitor). Samples were resolved by $10 \%$ SDS-PAGE and transferred onto nitrocellulose membrane. Block the membrane with $5 \%$ skim milk in TBS with 0.05\% Tween 20 . Incubation overnight at $4^{\circ} \mathrm{C}$ with primary antibodies (mouse anti-p53, anti-BAX \& antiBCL2 IgGs ) then incubated for $1 \mathrm{~h}$ at ambient temperature with anti-mouse IgG HRPconjugated secondary antibody in blocking solution. Bands were visualized by chemiluminescent substrate kit. Anti-actin goat polyclonal antibody and Rabbit anti-goat IgG HRP conjugated were used for equal loading confirmation. The density of bands was estimated as uncalibrated optical density using Image J software referenced to actin band (Burnette 1981).

\section{Cell viability analysis}

The viability of AD-MSCs was tested in different passages by adding equal volumes of the cell suspension and $0.4 \%$ trypan blue dye and then counting the clear and blue stained cells as alive and dead cells, respectively using a hemocytometer.

\section{Quantitative real-time RT-PCR}

Total RNA was extracted from testis samples using RNA easy Mini Kit (Invitrogen) according to the protocol. Reverse transcription was done 
using (SMART_PCR cDNA synthesis kit, Clontech Inc., Palo Alto, CA). Quantitative RT-PCR was performed in duplicate in $25 \mu \mathrm{L}$ mixture containing $1 \mu \mathrm{L}$ template cDNA, SYBR Green PCR Master Mix (Applied Biosystems), 10 pmol of each Primer for CD44 forward, GATGGAGAAAGCTCTGAGCATC and reverse, CACCTTCTTCGACTGTTGAC, and for GAPDH forward, AACTTTGGC- ATTGTGGAAGG and reverse, GTCTTCTGGGTGGCAGTGAT. Reactions were run in I Cycler iQ (Bio-Rad). The results were normalized to GAPDH mRNA level.

\section{Measurement of pro-inflammatory cytokines}

The level of serum TNF- $\alpha$, IL-6, and IL-10 were measured using an ELISA kit for each one (Ray Biotech, Georgia) according to the manufacturer's instructions.

\section{Histological preparation and testis histopathology score}

For histological and histopathological examinations, pieces of the testis were fixed in $10 \%$ neutral buffered formalin $\mathrm{pH}$ 7.2. Paraffin sections of 5 micrometers in thickness were prepared and then stained with haematoxylin and eosin stains. Seven sections of different animals were examined for each animal group. Five testis injury parameters (tissue vacuolization, cytoplasmic color fading, nuclear condensation, nuclear fragmentation and erythrocyte-stasis) were considered to score the testis injury according to Heijnen's method (2003).

\section{Statistical analysis}

All results are expressed as the mean $\pm \mathrm{S}$. E. of at least three independent experiments. Statistical significance of differences was analyzed with one-way analysis of variance followed by the Student Newman-Keuls T-test. Results were considered statistically significant when $\mathrm{P}<0.05$.

\section{RESULTS}

Morphological characterization of the cultured AD-MSCs

The segregated AD-MSCs began to stick to the plastic substrate of cell culture flasks inconsistently accomplishing various shapes three days after essential culture.
On day five, the cells turned out to be increasingly packed, the cells multiplied quickly and arrived at $90 \%$ confluency of primary culture. The cells were passaged about two times in $7^{\text {th }}$ and $9^{\text {th }}$ days. The cells from passage number three on days 9 were of homologous formed phenotype (Figure $1 \mathrm{a} \& \mathrm{~b}$ ).

\section{Flow cytometry analysis for AD-MSCs markers}

Flow cytometry examination demonstrated that AD-MSCs at passage 3 were positive for CD105

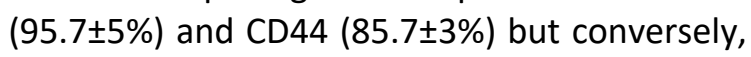

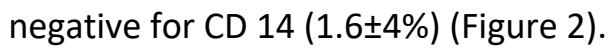

\section{Immunoblotting analysis for AD- MSCs markers}

Western blot detection of AD-MSCs markers at passage 3 revealed the detection of CD105 (95 $\mathrm{kDa})$ and CD44 (200 kDa). Densitometric analysis of the immune-reactive bands demonstrated that CD 105 and CD 44 was 4.4 \& 2.8 fold, respectively. While there was no reaction for CD14 (54 kDa) (Figure 3a,b).

\section{Cell viability of $A D-M S C s$}

AD-MSCs viability was estimated by trypan blueexclusion method. The experiment began with cell density at passage zero $112.9 \times 10^{3} \pm 12.58$ cells $/ \mathrm{ml}$. The cell viability at P1, P2 and P3 of ADMSCs reached $\left(538.5 \times 10^{3} \pm 84.70,593.9\right.$ $\left.x 10^{3} \pm 67.53 \& 616.3 \times 10^{3} \pm 57.51\right)$ respectively, compared with passage zero (Figure 4).

The results of $\mathrm{HCl}$ group were similar to that of the control group accordingly, the only results of the control group were shown.

AD-MSCs regulate P53 in the testis of rats administrated with As III $L \& H$ doses

Administration of As III in $\mathrm{L} \& \mathrm{H}$ doses elevates the level of p53 up to 2.4 and 3.5 fold, respectively versus those of control (Figure 5a) as determined from densitometric estimation (Figure 5b). Low and high doses of As III treatment was sufficient for expanding p53 to practically a large portion of the degree of control. Whereas As III L \& H + AD-MSCs coadministration decrease the level of p53 (Figure $5 a, b)$. So the impact of AD-MSCs displayed right around 1 and 1.3 folds alleviation in p53 level compared with the As III L\&H alone, respectively. 


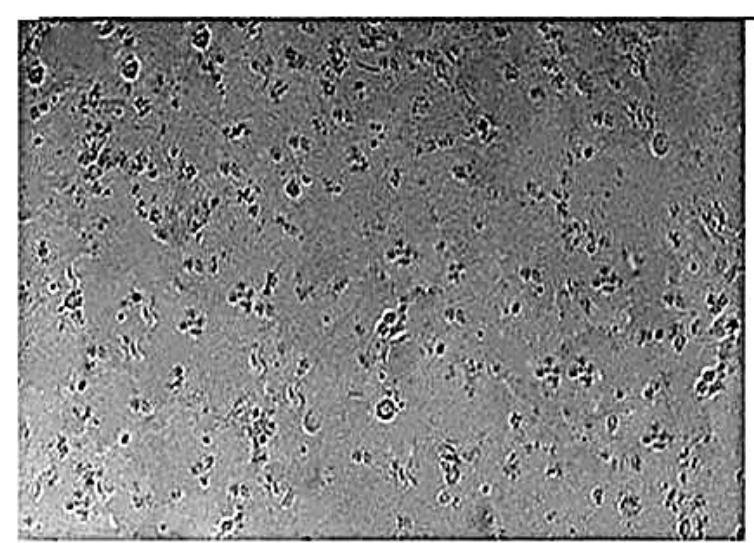

Zero day (P0)

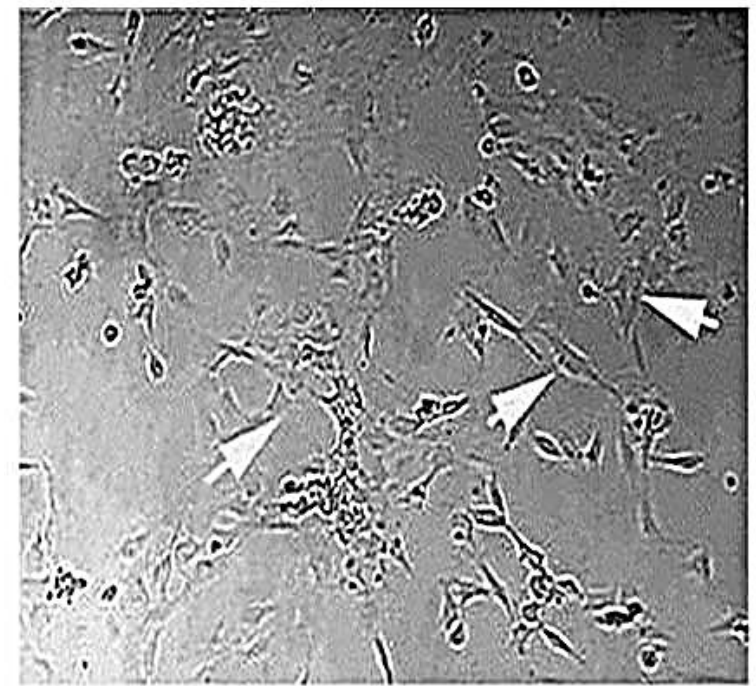

Three days

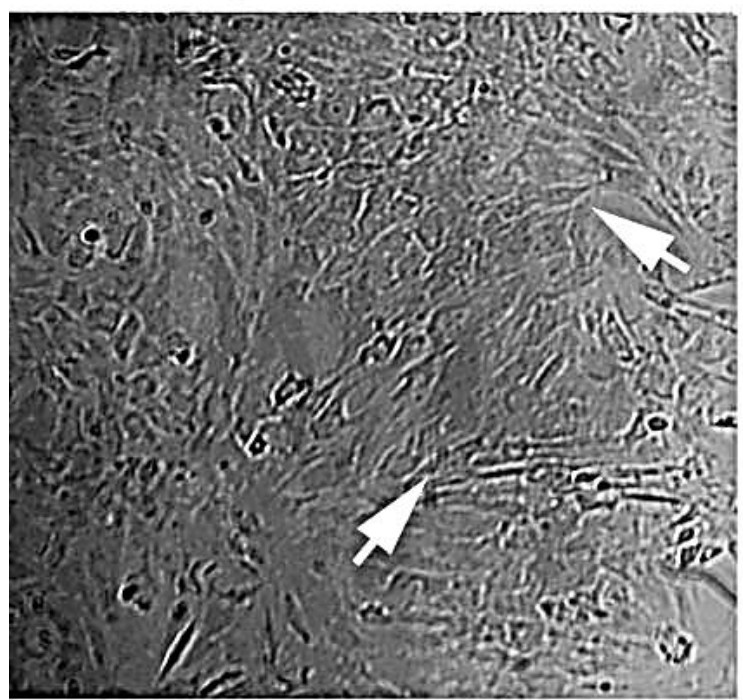

Seven days (P2)

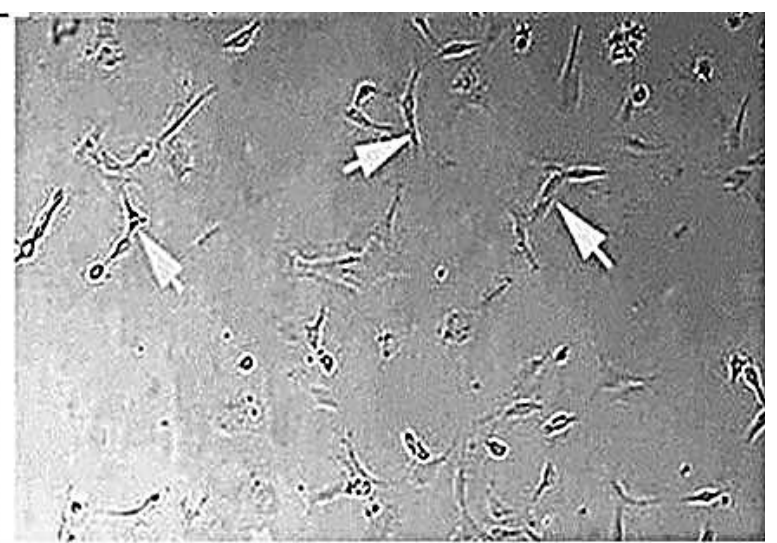

One day

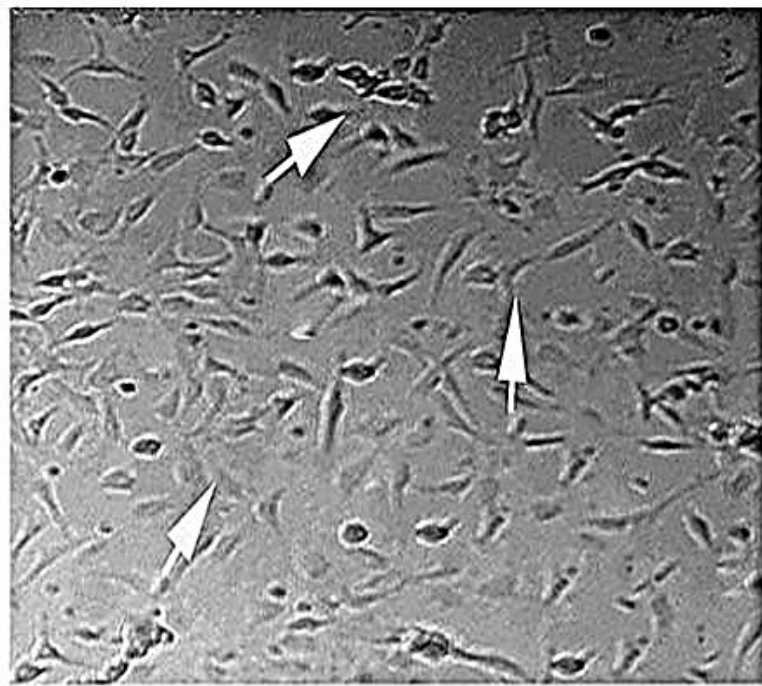

Five days (P1)

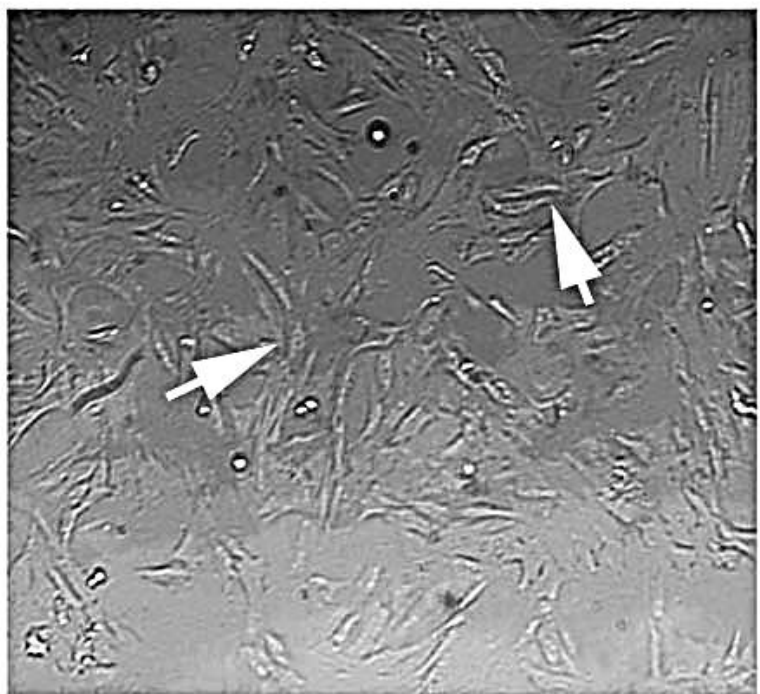

Nine days (P3)

Figure 1. Morphology of AD-MSCs detected by phase contrast microscopy. On zero-day of primary culture, the AD-MSCs are spherical, on one day AD-MSCs adhere to the plastic surface and appear with variable sizes and shapes (white arrow). On day 5 some cells appear spindle shape, the cells forming small colonies and reach about $85-90 \%$ confluency of primary culture. $2^{\text {nd }} \& 3^{\text {rd }}$ passaged of AD-MSCs appear homogenous in shape. Most of the cultured cells have fibroblastic appearance $(x 400)$. 

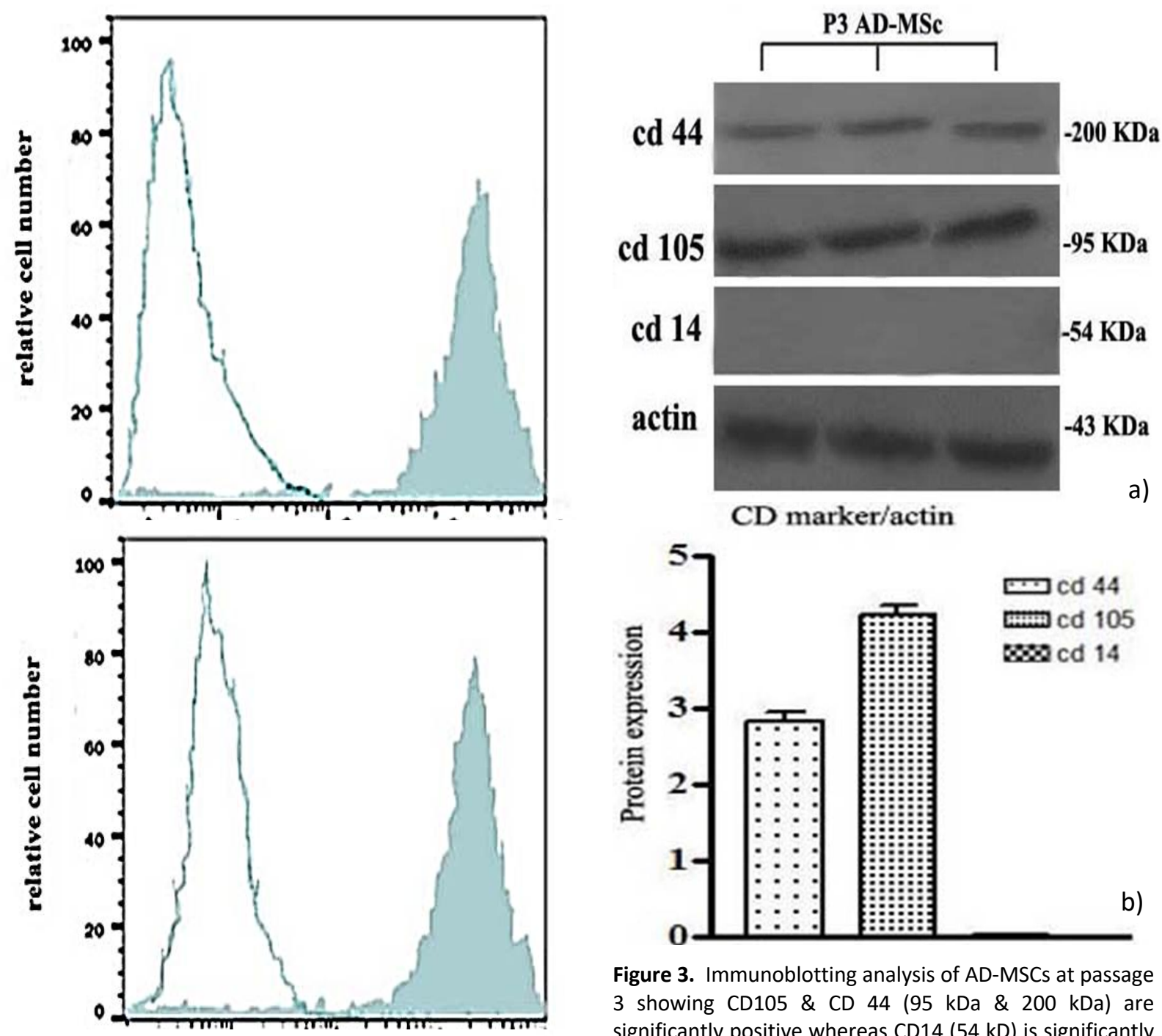

Figure 3. Immunoblotting analysis of AD-MSCs at passage 3 showing CD105 \& CD 44 (95 kDa \& $200 \mathrm{kDa}$ ) are significantly positive whereas CD14 (54 kD) is significantly negative (a). The proteins levels were quantitatively determined as a fold protein/actin. Data are presented as mean \pm S.E. from at least three independent experiments (b).

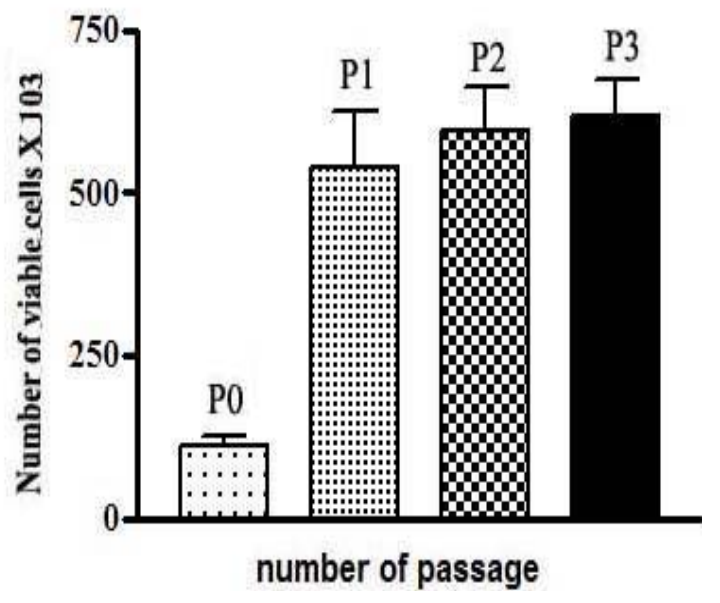

Figure 2. Flow cytometry analysis of the AD-MSCs at passage 3 . More than $98 \%$ of the cells are positive in the expression of superficial characteristics of stem cells CD105 and Cd44 but they are negative for CD14.

Figure 4. Mean viable AD-MSCs cells \pm SE at 1 to 9 days of culture (experiment began with cell density $112.9 \times 10^{3}$ cells $/ \mathrm{ml})$. 

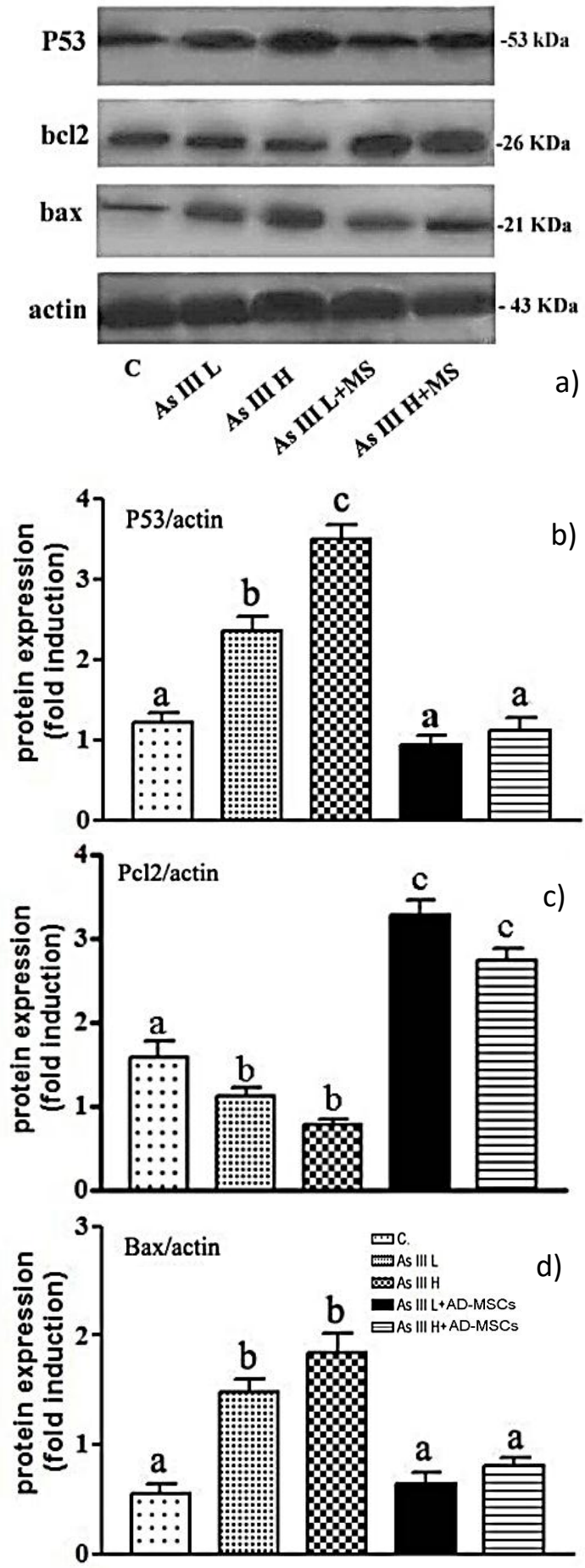

Figure 5. AD-MSCs stimulate the alleviation of P53 \& Bax and $B C L 2$ to increase in the testis of As III L\& $H$ treated rats. Testicular tissues were lysed and processed to western blot detection of $\mathrm{p} 53, \mathrm{bcl} 2$ \& Bax as described in methods. Equal protein loading was verified with anti-actin (a). Immunoblots were quantified denistometricaly for the effect of exposure to As III $\mathrm{L} \& \mathrm{H}$ and different treatments on P53, BCL2 \& Bax protein levels as fold induction of protein/actin ratio after normalization to the control level. Values in the same column with unlike superscript letters are significantly different at $P<0.05$. Data are representing as the mean $\pm S$.E. from at least three independent experiments $(b, c, d)$.
AD-MSCs effect on apoptotic markers in the testis of As III L\&H doses treated rats

$\mathrm{Bcl} 2$ as anti-apoptotic protein was found to be decreased by As III L \&H treatment whereas, a noticeable increase in the level of Bax as proapoptotic protein after As III L \&H treatment was detected (Figure 5a). Bcl2 level decreased almost 1.1 folds in As III L treatment and almost 0.7 folds in As III $\mathrm{H}$ versus to the control (Figure 5c). AD-MSCs co-treatment induced a sharp increase in $\mathrm{Bcl} 2$ level compared to As III L \& $H$ alone (Figure 5c). Bax level increased almost 1.5 folds in As III L treatment and around 1.8 folds in As III $\mathrm{H}$ versus to the control. In contrast to this, AD-MSCs decreased the level of Bax by 0.6 and 0.8 folds versus to As III $L \& H$ treatments (Figure 5d).

\section{qRT-PCR for CD44 gene expression in testicular tissue}

To evaluate the settlement of AD-MSCs in the testicular tissues, samples were taken for qRTPCR analysis from all groups of the experiment for quantification of CD44 mRNA expression. The only samples that give a detectable signal for CD 44 mRNA were those received AD-MSCs transplantation, (As III L\&H + AD-MSCS) experimental groups. The level of CD44 mRNA expression reached almost 8.3 and 5.5 folds for low and high As III doses transplanted with ADMSCs (Figure 6). But no expression of CD44 was noticed in control, As III L \& $\mathrm{H}$ treated rats. This observation confirms that AD-MSCs settled in testicular tissue of animals subjected to ADMSCs transplantation (Figure 6).

\section{Effect of AD-MSCs on pro-inflammatory cytokines}

The Serum TNF- $\alpha$, IL- 6 , and IL-10 in the blood of different treatment groups are shown in Figure $7 a, b, c)$. As III L \& H -treated rats showed a significant increase in the level of TNF- $\alpha(136.5 \%$ \pm 4.5 \& $205.8 \% \pm 3.8$ ) respectively. In addition to this, down regulation of IL- 6 , and IL-10 levels were obtained $(51.05 \% \pm 2.7$ \& $68.6 \% \pm 2.9$; $62.3 \% \pm 2.1 \& 82.2 \% \pm 1.7)$ respectively, versus control rats. The injection of AD-MSCs showed a significant reduction TNF- $\alpha$ levels in low and high doses (53.1 \% $\% 3.1 \quad \& 47.9 \quad \% \pm 3.8)$, respectively as well as an increase in IL-6, and IL10 levels by $(130.5 \% \pm 4.4 \& 163.1 \% \pm 3.7 ; 101.9$ 
$\% \pm 2.6 \& 236.3 \% \pm 5.4)$ versos As III L \& H treated rats. The protective effect of AD-MSCs appeared clearly as a reduction of the level of TNF- $\alpha$ and increase of IL-6, and IL-10 levels in low and high doses of arsenic.

\section{Light microscopic examination:}

Histological examination of normal testis of rats stained by H\&E in the control group (Figure 8a) appeared as normal histological structure: the testicles seemed encompassed and covered with a fibrous capsule called the tunica albuginea. The seminiferous tubules showed up firmly stuffed and lined by spermatogenic epithelium which framed of spermatogonisis stages. The Sertoli cells are also present in the epithelium of the seminiferous tubule. The seminiferous tubules were ensheathed by storm cellar layer, interstitial cells located between the seminiferous tubules.

In As III L group, there were great changes in the testicular structure including loss of regular spermatogenic epithelium stages arrangements and several degenerative germ cells were scattered in an irregular manner forming degenerative space. The cytoplasm is vacuolated with faintly stained nuclei. The vacuolization of the affected seminiferous tubules indicates obvious signs of hydropic degeneration. Also, the reduction in the number of interstitial cells leaving wide interstitium and intertubular space. Karyolitic nuclei of many spermatoginic cells and alumina of seminiferous tubule with empty sperms appeared in Figure $8 b, c$.

Microscopic examination of As III $\mathrm{H}$ group revealed serious and severe mutilation of the vast majority of the seminiferous tubules with loss of their ordinary histological structure. The tubules were contracted, decayed, and totally without spermatogenic epithelium leaving huge spaced empty areas. While many spermatogenic cells had shrunken pyknotic nuclei and other tubules filled with congested blood vessels in the interstitium (Figure 8d,e). In As III L \& H+ AD-MSCs groups remarkable normal features of the seminiferous tubules with repaired spermatogenic cells in the seminiferous tubules and the interstitial cell number are restored. Slight pyknotic nuclei throughout some spermategenic cells were detected beside little degeneration of spermatocytes of tubules was observed (Figure $8 f, g)$. Testis histophathological score was assessed by Heijnen's score, As III H groups recorded highest scores than As III L, Experimental groups of AD-MSCs showed significant decreasing of the score compared with As III L \& H groups (Figure 8h).

\section{DISCUSSION}

As III is toxic and induce apoptosis and actuated oxidative stress in rat hepatocellular carcinoma cells and testis. Furthermore, As III will obstruct the cell cycle at G2/M stage. It can likewise actuate apoptosis to cells at different stages of the cell cycle (Higuchi et al., 2013; Zubair et al., 2017 and Boregowda et al., 2018).

In the present investigation, there was a noteworthy increment in testicular P53 and Bax levels and abatement of $\mathrm{BCl} 2$ level after As III L $\& H$ administration. The current result was in concordance with different data confirming the liver and kidney harm actuated by As III (Charles 2014 and Mehrzadi et al., 2018). Sodium arsenite-initiated oxidative stress, change in p53 pathway and apoptosis of testicles were observed in rat (Banik et al., 2014; Boregowda et al., 2018). Also, Prockop (2012) reported that Bax protein is an apoptotic factor and it is actuated in states of oxidative stress instigated apoptosis.

Numerous reports have examined the effect of AD-MSCs differentiation to myocytes, hepatocytes, neural cells and even epithelial cells of the lung, kidney and skin. (Komori et al., 2005; El Kasaby et al, 2018). The remedial capability of AD-MSCs depends on its antifibrotic, regenerative, and reparative properties; it could improve the harmed tissues (Lodi et al., 2011) and different illnesses including wound healing, neurological and lung infections, diabetes and cystic fibrosis (Fazeli et al., 2018; Sherif et al., 2018). The present result clarified the role of treatment with AD-MSCs in inhibition of the level of P53 and Bax in the testis of ASIII L\&H treated mice, where AD-MSCS injection significantly stimulated the levels of $\mathrm{BCl} 2$ on These data correspond with previous reports in the role of MSCs with antioxidative and as anti-inflammatory capabilities (Burova et al., 2013). 


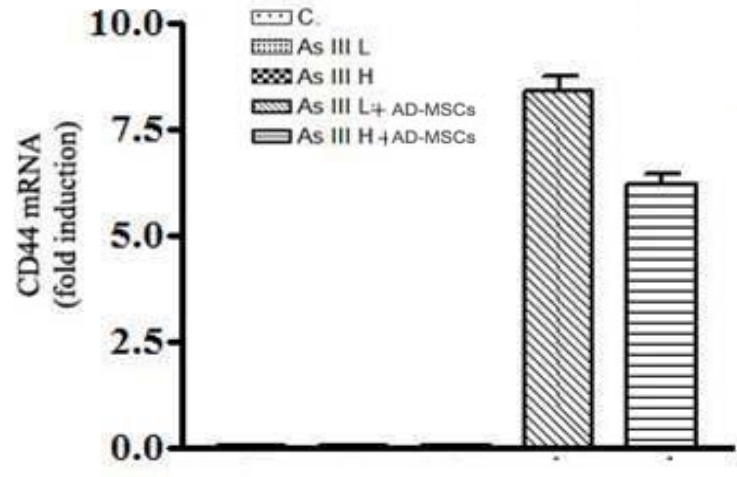

Figure 6. The mRNA of CD44 was quantified in testicular tissues by qRT-PCR in control and different treatments. CD44 is positively reacted in AD-MSCs co-administration groups, values were normalized by GAPDH corresponding level. Presented Data are shown by mean \pm S.E. from three independent experiments.

a) TNF- $\alpha$

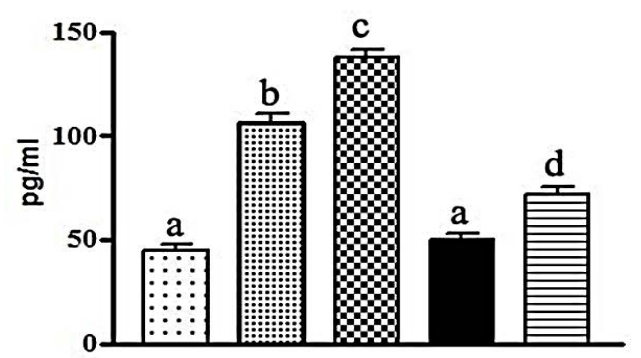

b)

IL-6

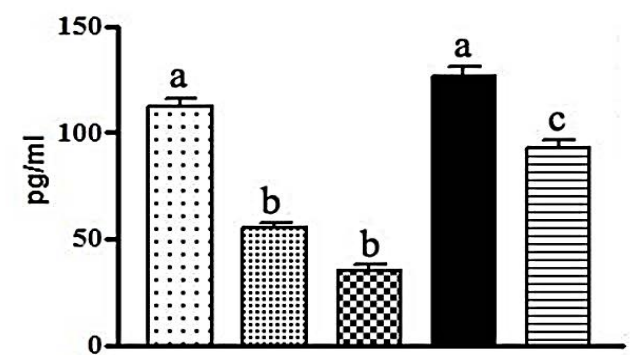

c)
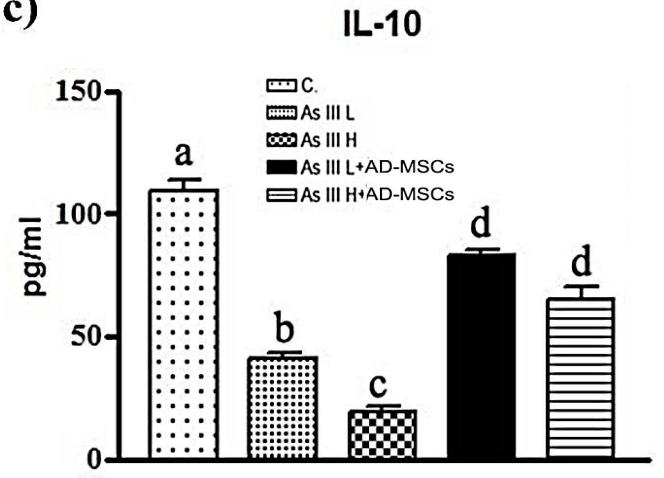

Figure 7. Showing the effect of As III L \& H and its combination with D-MSCs on the levels of proinflammatory cytokines TNF- $\alpha$, IL-6, and IL-10 determined in serum $(a, b \& c)$. Data are representing as the mean $\pm S$.E. Unlike superscript letters in the same column are significantly different at $\mathrm{P}<0.05$.
For instance, Sheri et al., 2015 and Wang et al., 2017 recommended that the BM-MSCs induced decreases in caspase- 3 , and Bax levels in rat renal tissue treated with cytotoxic drug as cisplatin or heavy metal as cadmium. Furthermore, MSCs have been found to improve the testicular tissue toxicity due to their antioxidative defensive mechanism against oxidative stress (Hassan and Alam., 2014 and Roushandeh et al., 2017).

Some investigations have indicated that a few cells separated from mesenchymal stem cells could communicate germ cells explicit markers (Mazaheri et al., 2011). The present result shows that AD-MSCs at passage 3 revealed positive reactions for $\mathrm{CD} 105$ and $\mathrm{CD} 44$ while the protein expression level for CD14 gave a negative reaction.

Khurana et al., (2013) work revealed that negative expression for the antigens CD45 and CD31 in the MSC, despite CD44 and CD90 were expressed observably. In the present study, the gene expression analysis by qRT-PCR revealed the presence of AD-MSCs in the testis of rats by identifying the expression of CD44 positive cells in testis. The total count of CD44 positive cells showed a significant increase in stem cellstreated As III L\&H groups as compared to As III L\&H groups alone which lacked CD44.

A noteworthy increment of TNF- $\alpha$ levels was appeared in As III groups when compared to control. A comparable finding was seen by Sherif et al., (2018), affirming the toxicity of arsenic in several organs in the male rat. On the other hand, expanded degrees of oxidative stress due to exposure to arsenic were reported by others (De Vizcaya-Ruiz et al., 2009). The Oxidative stress stimulates cascades of inflammatory mediators including TNF- $\alpha$ causing cytotoxic effects and triggering of apoptosis (Liu et al., 2014 and Adikwu et al., 2014).

The present investigation indicated that treatment injured rat with AD-MSCs ameliorated the increased level of TNF- $\alpha$ protein compared to As III L \&H groups. In contrast, AD- MSC administration increased the levels of IL-10 and IL- 6 in As III L\& H -treated rats. 


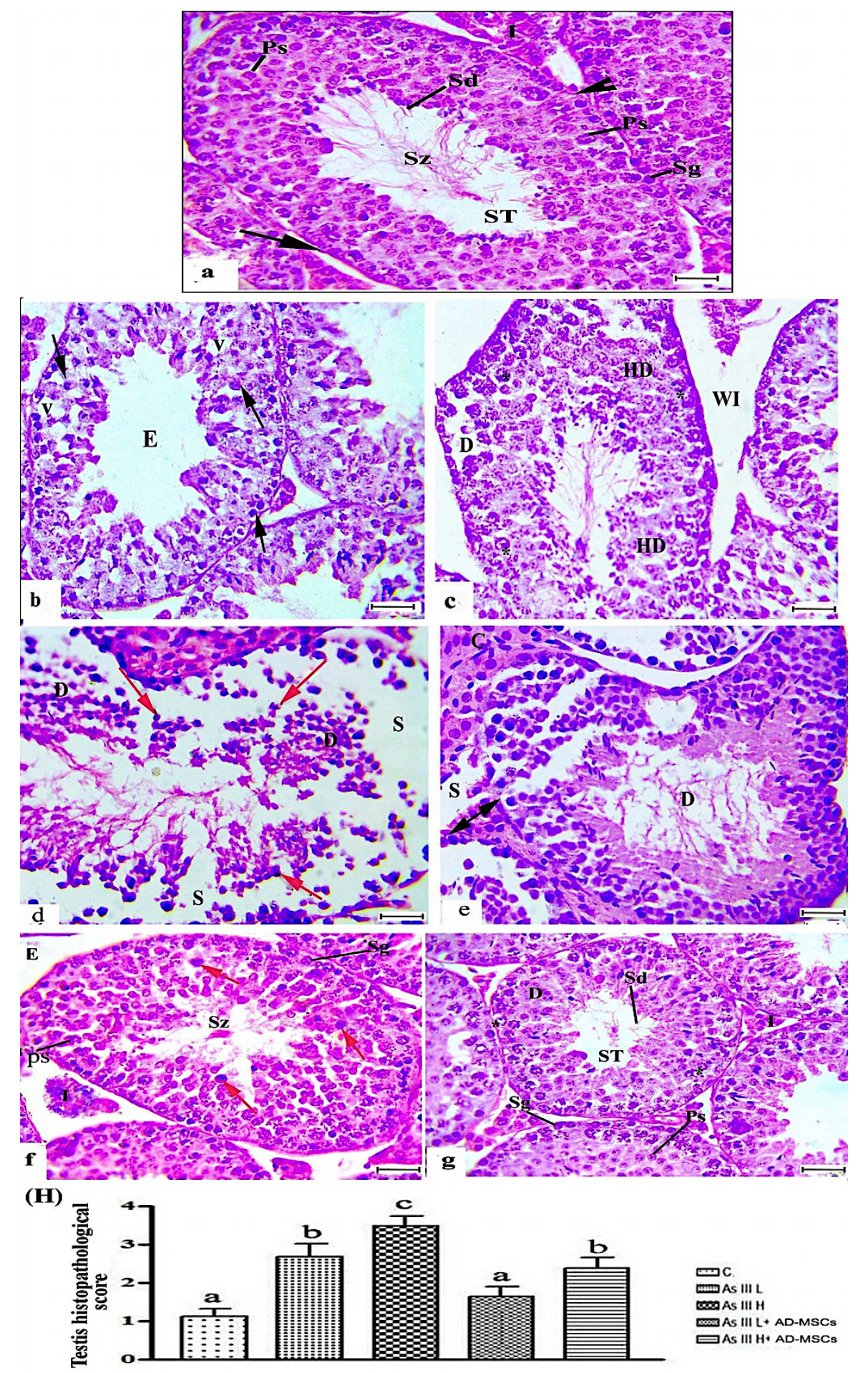

Figure 8. Light microscopic examination of testis sections of rats in the control and different treatments: Showing, normal structure of the testis and its adjacent seminiferous tubules (ST), boundary tissue (arrows), spermatogonia (Sg), primary spermatocytes (PS), spermatids (Sd), and spermatozoa (SZ) in each tubule, interstitial cells (I) and Sertoli cells (SC) are observed (arrows head) (a). In As III L group, several degenerative germ cells (D), spermatogenic cells had karyolytic nuclei (black arrow), vacuolization (V), hydropic degeneration (HD) and seminiferous tubule Lumina with empty sperms (E) (b \&c). In As III $\mathrm{H}$ group, severs mutilation and shrunken of the vast majority of the seminiferous tubules leave huge space empty area (E), pyknotic nuclei of many spermatogenic cells (red arrow) and between tubules filled with congestion (C) were observed (d \& e). As III L \& H+ AD-MSCs groups: Showing Repair and improvement in the structure of the cell of the seminiferous tubules (ST) in two groups. But few pyknotic nuclei were detected in some spermategenic cells (red arrow) in As III L+ AD-MSCs group. However in As III H+ AD-MSCs group moderate degeneration (D) of spermatocytes of tubules was stilled appeared ( $f \& g)(H \& E, B a r=50 \mu \mathrm{m})$. In testis histophathological score, Data are mean \pm S.E. from two independent experiments. Values in the same column with unlike superscript signs are significantly different $(P<0.05)(h)$. 
Related studies have shown that upon MSC migration to the injured place, it becomes activated and secrete growth factors and cytokines such as IL- 6 and platelet-inferred development factor (EL-Far et al., 2012; El Kasaby et al. , 2018). It may likewise up regulate IL-10 cytokine in the unhealthy organ (Metwally et al., 2017). A few investigations have indicated that these cytokines had a regulatory effect in the relocation of $\mathrm{BM}-\mathrm{MSCs}$ and repairing harmed tissue (Kholodenko et al., 2013). Also, cytokines can manage cell processes, for example, chemotaxis, cell expansion, signaling of cell and angiogenesis in the harmed area (Asahara et al., 1999).

In the present study, light microscopic assessment of testicles in rats of the control group showed ordinary develops seminiferous tubules. Severe histopathological change of testis result by oral administration of As III in rats as in As III L \& H groups testicular tissue has many damages compared to the control. These damages include congestion between tubules, hydropic degeneration in germ cells, vacuolated cytoplasm and Karyolitic nuclei of many spermatoginic cells. It was found that sever declined spermatogenic cells due to an essential impact on the cell-to-cell intersections among Sertoli and germ cells lead to germ cell apoptosis (Blanco-Rodríguez and MartínezGarcía 1998). Furthermore, exhaustion of germ cells due to oxidative stress is in concurrence with other reports (Aggarwal et al., 2007; Bal et al .,2012). In the present result, AD- MSCs improved the harmful effect of As III L \& H in testicular tissues. However, a few investigations have indicated the gainful effect of MSCs in testicular injuries incited by various agents in different organs and animals (Cakici et al., 2015; Elawady et al., 2016). (Lue et al., 2007) suggested, the blood-testis barrier may help the MSCs to preserve from immunologic responses. The result of the current study revealed that the injection of AD-MSCs into rats caudle vein could help to repair severe damage in testis induced by arsenic.

\section{CONCLUSION}

This work was done to show the effective role of AD- MSCs against As III L \&H induced testicular damage. AD-MSCs transplantation evoked changes in pro-inflammatory cytokines levels and expanded apoptosis boundary levels in rat testis. Also, the present results demonstrate the improvement effect of $A D$ MSCs on the histological structure of testis after exposure to As III L \& H.

\section{Acknowledgements}

This work was supported by the laboratory of molecular cell biology, zoology department, Faculty of Science, Assiut University, Egypt.

\section{CONFLICT OF INTEREST}

Authors declare that they have no conflicts of interest.

\section{FUDING}

There is no financial support for this study.

\section{REFERENCES}

Adikwu E, Deo O, Geoffrey OP, Enimeya AD (2014). Lead Organ and Tissue Toxicity: Roles of Mitigating Agents (Part 2) Br J Pharmacol Toxicol, 5:1-15.

Aggarwal M, Wangikar PB, Sarkar SN et al. (2007). Effects of low-level arsenic exposure on the developmental toxicity of anilofos in rats. J Appl Toxicol, 27:255-61.

Asahara T, Takahashi T, Masuda H., Kalka C, Chen D, Iwaguro H, Inai Y, Silver M, Isner JM (1999). VEGF contributes to postnatal neovascularization by mobilizing bone marrowderived endothelial progenitor cells. The EMBO Journal,18: 3964-3972.

Atalla SS, Saleh HA, Gawad AS and Mohamed H (2018). Histological study on the effect of adipose tissue-derived mesenchymal stem cells on the testis of chemically induced castration model by calcium chloride in adult albino rats. EJH journals, 10: 21608/.5516.

Bal R, Türk G and Tuzcu M, et al. (2012). Assessment of imidacloprid toxicity on reproductive organ system of adult male rats. J Environ Sci Health B, 47:434-44 .

Balakumar B, Ramanathan K, Kumaresan S and Suresh R. (2010). DNA damage by sodium arsenite in experimental rats: Ameliorative effects of antioxidant vitamins $\mathrm{C}$ and $\mathrm{E}$. Indian Journal of Science and Technology, 3:322-327.

Banik GN, Chakraborty I and Mukhopadhyay PK (2014). Ameliorative effect of $\alpha$-tocopherol and ascorbic acid on the accessory reproductive glands of adult male rats in arsenic toxicity. International Journal of Pharmaceutical Sciences Review and Research, 26: 282-287. 
Birch JM, Blair V, Kelsey AM, Evans DG, Harris M, Tricker KJ, et al. (1998). Cancer phenotype correlates with constitutional TP53 genotype in families with the Li-Fraumeni syndrome. Oncogene, 17:1061-8 .

Blanco-Rodríguez J and Martínez-García C (1998). Apoptosis precedes detachment of germ cells from the seminiferous epithelium after hormone suppression by short-term oestradiol treatment of rats. International Journal J Andrology.A , 21: 109-115.

Boregowda SV, Krishnappa V, Strivelli J, Haga CL, Booker CN and Donald G (2018). Basal p53 expression is indispensable for mesenchymal stem cell integrity Phinney. Cell Death \& Differentiation, 25: 677-690.

Burnette, W.N. (1981). Western blotting': electrophoretic transfer of proteins from sodium dodecyl sulfate-polyacrylamide gels to unmodified nitrocellulose and radiographic detection with antibody and radioiodinated protein A". Analytical Biochemistry 112: 195203.

Burova E, Borodkina A, Shatrova A, Nikolsky $\mathrm{N}$ and Sublethal (2013). oxidative stress induces the premature senescence of human mesenchymal stem cells derived from endometrium. Oxidative Med Cell Longev, 1-12.

Cakici C, Buyrukcu B, Duruksu G, Haliloglu AH, Aksoy $A$, Isik $A$, Uludag $O$, Ustun $H$, Subası $C$ and Karaoz E (2013). Recovery of fertility in azoospermia rats after injection of adiposetissue-derived mesenchymal stem cells: the sperm generation. Biomed Res Int, 529589.

Chang S I, Jin B, Youn P, Park C, Park J D and Ryu D $Y$ (2007). Arsenic-induced toxicity and the protective role of ascorbic acid in mouse testis. Toxicology and Applied Pharmacology, 218: 196-203.

Charles CA (2014). Effect of arsenic trioxide poisoning on hematological parameters, liver marker enzymes and kidney of male albino rats. Pinnacle Biological Sciences. 139: 262-265 .

De Vizcaya-Ruiz A, Barbier O, Ruiz-Ramos R, and Cebrian M E (2009). Biomarkers of oxidative stress and damage in human populations exposed to arsenic. Mutation Research, 674: 85-92.

Dominici M, Le Blanc K, Mueller I, Slaper-Cortenbach I, Marini F C, Krause D S, et al. (2006).Minimal criteria for defining multipotent mesenchymal stromal cells. The International Society for Cellular Therapy position statement. Cytother, 8: 315-317.

El Kasaby ANE, Ghaly MAE, Abo Zeid AAE and Fayed M I (2018). Therapeutic potential of adipose derived mesenchymal stem cells in regeneration of gastric ulcer in rats $\mathrm{JMH}$, 10:21608- 2367.

Elawady MA, Elmaghrabi MM, Ebrahim N, Elawady MA, Sabry D, Shamaa A, Ragaei A (2016). Therapeutic potential of bone marrow derived mesenchymal stem cells in modulating astroglyosis of surgical induced experimental spinal cord injury. Adv Biosci Biotech, 7:251.

El-Far MA, Gabr M, El-Halawani SM, Ibrahim R, Khater SM, Refaie AF and Ghoneim MA (2012). Novel evidence of restoring and augmenting antioxidant defense after treatment of diabetic rats using stem cells. Current Topics in Biochemical Research, 14: 25-37.

Fazeli Z, Abedindo A, Omrani MD, Ghaderian SMH (2018). Mesenchymal stem cells(MSCs) therapy for recovery of fertility: a systematic review. Stem Cell Rev,14:1-12.

Hala GM, Hala FAE, Nora E, Shaheen M, Magda SH, Afifi and Nura I A (2017). Role of Mesenchymal Stem Cells in the Treatment of Testicular Toxicity Induced by Lambda-Cyhalothrin in Rats. wulfenia journal, 24: 10.

Har Harsan, H, Mariya, S, Islam, AA, Wahjoepramono, EJ, Yusuf, I (2015). Isolalsolation of Mesenchymal Stem Cells from Adipose Tissue. The Indonesian Biobbiomedical Journal, 7(3), 153-6.

Hassan Al, Alam SS (2014). Evaluation of mesenchymal stem cells in treatment of infertility in male rats. Stem Cell Res Ther, 5:131.

Heijnen B H, Straatsburg I H, Gouma D J, van Gulik TM. (2003). Decrease in core liver temperature with 10 degrees $C$ by in situ hypothermic perfusion under total hepatic vascular exclusion reduces liver ischemia and reperfusion injury during partial hepatectomy in pigs. Surgery, 134:806-817.

Higuchi M, Dusting GJ, Peshavariya H, Jiang F, Hsiao ST, Chan EC et al. (2013). Differentiation of human adipose-derived stem cells into fat involves reactive oxygen species and Forkhead box $\mathrm{O} 1$ mediated upregulation of antioxidant enzymes. Stem Cells Dev, 22:878-88.

Hughes MF (2002). Arsenic toxicity and potential mechanisms of action. Toxicol. Letters, 33:1-16.

Jung YL, Chang HJ, Jin AJ, Seong MK, Chung HR, Yun $H$, and et al. (2011). Therapeutic effects of human umbilical cord blood-derived mesenchymal stem cells after intrathecal administration by lumbar puncture in a rat model of cerebral ischemia. Stem Cell Res Ther, 2:38-42.

Kholodenko IV, Konieva AA, Kholodenko RV and Yarygin KN (2013). Molecular mechanisms of migration and homing of intravenously 
transplanted mesenchymal stem cells. Journal of Regenerative Medicine \& Tissue Engineering, 1218 .

Khurana SS, Riehl TE, Benjamin D, Moore BD, Fassan M, Rugge M, Romero-Gallo J, Noto J, Peek RM, Stenson WF and Mills JC (2013). The Hyaluronic acid receptor CD44 coordinates normal and metaplastic gastric epithelial progenitor cell proliferation. The Journal of Biological Chemistry,288: 16085-16097 .

Kim JYJ, Seung GL, Yong Chung J, Young Kim J (2011). Arsenic trioxide-induced apoptosis in TM4 Sertoli cells: The potential involvement of p21 expression and p53 phosphorylation. Toxicology, 285:142-51.

Komori M, Tsuji S, Tsujii M, Murata $H$, lijima $H$, Yasumaru M, Nishida T, Irie T, Kawano S, Hori $M$ (2005). Efficiency of bone marrow-derived cells in regeneration of the stomach after induction of ethanol-induced ulcers in rats. J Gastroenterol, 40: 591- 599.

Li Z, Fan D, Xiong D (2015). Mesenchymal stem cells as delivery vectors for anti-tumor therapy. Stem Cell Investig, 2: 6.

Lim CY, Han Jl, Kim SG, Lee CM, Park HM (2016). Evaluation of autologous bone marrowderived mesenchymal stem cells on renal regeneration after experimentally induced acute kidney injury in dogs. Am J Vet Res, 77:208-17.

Liu LJ, Trimarchi R, Navarro P, Blasco MA, Keefe DL (2003). Oxidative stress contributes to arsenic induced telomere attrition, chromosomal instability and apoptosis. J. Biol. Chem, 278:31998-32004.

Liu P, Feng Y, Wang, Zhou Y (2014). Therapeutic action of bone marrow-derived stem cells against acute kidney injury. Life Sci, 115:1-7.

Lodi D, lannitti T, Palmieri B (2011). Stem cells in clinical practice: applications and warnings. J Exp Clin Cancer Res, 30:9.

Lue Y, Erkkila K, Liu PY, Ma K, Wang C, Hikim AS, Swerdloff RS (2007). Fate of bone marrow stem cells transplanted into the testis, potential implication for men with testicular failure. The American Journal of Pathology, 170: 899-908.

Mahajan L, Kumar P V, Raina R and Sood S (2018). Potentiating effect of imidacloprid on arsenicinduced testicular toxicity in Wistar rats BMC Pharmacology and Toxicology, 19:48.

Mandal TK, Das NS (2012). Testicular gametogenic and steroidogenic activities in chlorpyrifos insecticide-treated rats: a correlation study with testicular oxidative stress and role of antioxidant enzyme defence systems in Sprague-Dawley rats. Andrologia, 44:102-15.

Mazaheri Z, Movahedin M, Rahbarizadeh F, Amanpour S (2011). Different doses of bone morphogenetic protein 4 promote the expression of early germ cell-specific gene in bone marrow mesenchymal stem cells. In Vitro Cell Dev Biol Anim, 47: 521- 525 .

Mehrzadi S, Bahrami N, Mehrabani M, Motevalian M, Mansouri E, Goudarzie M (2018). Ellagic acid: A promising protective (5) remedy against testicular toxicity induced by arsenic. Biomedicine \& Pharmacotherapy, 103: 14641472.

Melanie K, Vandana K, Thomas GH, John MC, Brenda R, Richard AG (2012). Stem Cell-Derived Extracellular Matrix Enables Survival and Multilineage Differentiation within Superporous Hydrogels. Biomacromol, 13:963-973 .

Millman JR, Pagliuca FW (2017). Autologous pluripotent stem cell-derived $\beta$ - like cells for diabetes cellular therapy. Diabetes, 66: 11111120.

Monsefi M, Fereydouni B, Rohani LC, Talaei T (2013). .Mesenchymal stem cells repair germinal cells of seminiferous tubules of sterile rats. Iran J Reprod MedJul, 11: 537-544.

Pant N, Murthy RC, Srivastava SP (2004). Male reproductive toxicity of sodium arsenite in mice. Human and Experimental Toxicology, 23:399-403.

Prockop DJ (2012). A long-awaited discovery: hypoxia prevents mouse cells from undergoing spontaneous p53-dependent transformation. Cytotherapy, 14:1029-31.

Roushandeh AM, Bahadori $\mathrm{M}$, Roudkenar $\mathrm{MH}$ (2017). Mesenchymal stem cell-based therapy as a new horizon for kidney injuries. Arch Med Res, 48:133-46.

Sanghamitra S, Hazra J, Upadhyay SN, Singh RK, Amal RC (2008). Arsenic induced toxicity on testicular tissue of mice. Indian J Physiol Pharmacol. 52:84-90.

Sarkar M, Chaudhari GR, Chattopadhyay A, Biswas NM (2003). Effect of sodium arsenite on spermatogenesis, plasma gonadotrophins and testosterone in rats. Asian Journal of Andrology, 5: 27-33.

Shen H, Xu W, Zhang J, Chen M, Martin F L, Xia Y, Zhu Y G (2013). Urinary metabolic biomarkers link oxidative stress indicators associated with general arsenic exposure to male infertility in a Han Chinese population. Environmental Science and Technology, 47: 8843-8851.

Serhal R, Saliba N, Hilal G, Moussa M, Hassan SG, El Atat O, Alaaeddine N (2019). Effect of adiposederived mesenchymal stem cells on hepatocellular carcinoma: In vitro inhibition of carcinogenesis .World J Gastroenterol, 25: 567583. 
Sherif IO, Sabry D, Abdel-Aziz A, Sarhan4 Sherif OM, et al. (2018). The role of mesenchymal stem cells in chemotherapy-induced gonadotoxicity. Stem Cell Research \& Therapy, 9:196

ShirzeilyM H, Pasbakhsh P, Amidi F, Kobra J (2013). Comparison of differentiation potential of male mouse adipose tissue and bone marrow derived-mesenchymal stem cells into germ cells Iran J Reprod Med, 11: 965-976.

Singh TS, Pant K K (2004). Equilibrium, kinetics and thermodynamic studies for adsorption of $\mathrm{As}$ (III) on activated alumina. Separation and Purification Technol, 36:139-147.

Tchounwou PB, Patlolla AK, Centeno JA (2003). Carcinogenic and Systemic Health effects associated with arsenic exposure-A critical review. Toxicol Pathol, 31:575-588.

Wang YJ, Yan J, Zou XL, Guo KJ, Zhao Y, Meng CY, Yin $F$, Guo L (2017). Bone marrow mesenchymal stem cells repair cadmium-induced rat testis injury by inhibiting mitochondrial apoptosis. Chem Biol Interact, 271:39-47.
Wang LZ, Xu R, Jia XY, Jiang JF, Han XY (2006). Effects of Arsenic (AsIII) on Lipid Peroxidation, Glutathione Content and Antioxidant Enzymes in Growing Pigs. Asian-Australasian Journal of Animal Sciences, 19: 727-733.

Zubair M, Ahmad M, Qureshi Z I ( 2017). Review on arsenic-induced toxicity in male reproductive system and its amelioration. Wiley Online Library DOI, 10:1111-12791 .

Zuk PA (2010). The adipose-derived stem cell: Looking back and looking ahead. Mol Biol Cell, 21:1783-7 .

Zuk P, Min Z, Peter A, Daniel A, Jerry I, Hiroshi M, Zeni C, John K, Prosper B, Marc H (2002). Human Adipose Tissue Is a Source of Multipotent Stem Cells. Molecular Biology of the Cell, 3: 42794295. 


\section{Egyptian Association for Cancer Research (EACR)}

http://eacr.tanta.edu.eg/

EACR is an NGO society that was declared by the Ministry of Social Solidarity (Egypt) No. 1938 in 19/11/2014 based on the initiative of Prof. Mohamed Labib Salem, the current Chairman of EACR. EACR aims primarily to assist researchers, in particular young researchers in the field of cancer research through workshops, seminars and conferences. Its first international annual conference entitled "Anti-Cancer Drug Discovery" was successfully organized in April 2019 (http://acdd.tanta.edu.eg). Additionally, EACR aims to raise the awareness of the society about the importance of scientific research in the field of cancer research in prediction, early diagnosis and treatment of cancer. EACR is also keen to outreach the scientific community with periodicals and news on cancer research including peer-reviewed scientific journals for the publication of cutting-edge research. The official scientific journal of EACR is "International Journal of Cancer and biomedical Research (IJCBR: https://jcbr.journals.ekb.eg) was successfully issued in 2017 and has been sponsored by the Egyptian Knowledge Bank (EKB: www.ekb.eg).

\section{EACR Chairman,}

Prof. Mohamed Labib Salem, PhD

Professor of Immunology

Faculty of Science, Tanta Universiy, Egypt 
International Journal of Cancer and Biomedical Research (IJCBR), a publication of the Egyptian Association for Cancer Research (EACR), is a peer-reviewed online journal published quarterly. The journal allows free access (Open Access) to its contents and permits authors to self-archive a final accepted version of the articles on any OAl-compliant institutional / subject-based repository.

\section{Aim And Scope}

Aim: The main aim of IJCBR is to attract the best research in animal and human biology in health and diseases from across the spectrum of the biomedical sciences at the molecular, cellular, organ, and whole animal levels especially those that are related to cancer research, including causes, prediction, diagnosis, prognosis and therapy.

Scope: It is essential reading for all researchers interested in biochemistry, cancer, microbiology, nutrition, physiology, genetics, immunology, epidemiology, medical economics, human biology, bioinformatics, biotechnology, nanotechnology, and disease modeling.

\section{Publication Ethics}

Researchers should conduct their research from research proposal to publication in line with the best practices and codes of conduct of relevant professional bodies and/or national and international regulatory bodies. IJCBR accepts manuscripts prepared in accordance with the "Uniform Requirements for Submission of Manuscripts for Biomedical Journals adopted by the International Committee of Medical Journal Editors (ICMJE) and the Committee on Publication Ethics (COPE). Details of ICMJE and COPE are available at http://www.icmje.org/ and http://publicationethics.org/

\section{Peer Review Process}

After the IJCBR editor receives a manuscript, the first step is to confirm that the manuscript meets the journal's rules for content and format, including similarity check (plagiarism) which should be less than $25 \%$. If the manuscript meets the journal's rules, the editor then assign it to the double-blind peer review process. The IJCBR editor send the manuscript to at least two experts in the field for RIGOROUS scientific evaluation. The experts called peer reviewers - will then prepare a report that assesses the manuscript and return it to the editor through the IJCBR portal. Upon the first submission, this reviewing process takes about 4 to 6 weeks. After reading the peer reviewer's report, the editor will decide one of the following four options:

1. Reject the manuscript.

2. Accept the manuscript

3. Ask the authors to revise and resubmit the manuscript after responding to the peer reviewers' feedback.

4. Ask for peer-review from additional reviewers.

If the authors resubmit the manuscript, the IJCBR editor will ask the same peer-reviewers to look over the manuscript again to confirm that their concerns have been addressed. This is called re-review process. This second revision (if applicable) takes about another 4 to 6 weeks. At this point, the abstract of the article appears in press. The online publication (the PDF format) of the final version of the manuscript takes from 2 to 4 weeks. As such, the total publication cycle takes from 2 to 4 months. This cycle can be reduced to 4 to 6 weeks (fast track publication) for the manuscripts with outstanding findings.

The peer-review process used by IJCBR includes comments on errors in the study's methods or analysis that raise questions about the findings, or sections that need clearer explanations. The peer-review process also includes the importance and novelty of the manuscript and its interest to the journal's audience. The IJCBR uses double-blind review, which means that both the reviewers and authors identities are concealed from the reviewers, and vice versa, throughout the review process. To facilitate this, authors need to submit a Title Page containing the Authors details and Blinded Manuscript with no author details as 2 separate files. 


\section{Publisher}

The International Journal of Cancer and Biomedical Research (IJCBR) is an International and interdisciplinary journal of preclinical and clinical studies in the area of cancer and biomedical research. It is a peer-reviewed journal in English, published quarterly (in March, June, September, and December) by the Egyptian Association for Cancer Research (EACR) in both print and online formats (4 issues making a volume). Special issues or supplements may also be produced from time to time upon agreement with the Editorial Board.

\section{Scope}

The main aim of IJCBR is to attract the best research in animal and human biology in health and diseases from across the spectrum of the biomedical sciences at the molecular, cellular, organ, and whole animal levels especially those that are related to cancer research, including causes, prediction, diagnosis, prognosis and therapy.

\section{Publication Fees}

The journal does charge for submission, processing or publication of manuscripts (2000 LE for Egyptians or $\$ 300$ for non-Egyptians; EACR members receive 15\% discount on publication). Of them Peer-review fees (300 LE) should be paid on submission (non-refundable). For the fast track production of the accepted manuscript, another $500 \mathrm{LE}$ is paid.

General specifications for different types of article

- Submitted manuscripts should not have been published previously, except in a limited form (e.g. short communication to a symposium or as part of MSc or PhD theses) and should not be under consideration for publication by other journals.

- All co-authors should agree with the content of the manuscript. Authors must have obtained permission to use any copyrighted material in the manuscript before submission.

\section{IJCBR publishes different types of articles}

- Original Article (6000 words with $\mathbf{4}$ tables and $\mathbf{4}$ figures, maximum $\mathbf{8}$ display items): Articles with novel findings are the target of IJCBR. Articles presenting a detailed description of a new technique, comparison of existing methods, meta-analyses with comprehensive and in-depth discussion are considered. Papers in a numbered series are not accepted unless all are submitted at the same time.

- Short communications or case study (3000 words with 4 display items): Short communications present exceptionally exciting, novel or timely contents are considered. They will be peer-reviewed in the same way as research papers. The references are restricted to 15 .

- Reviews or systematic review (9000 words with $\mathbf{1 0}$ display items): They are invited by the Editorial Board or unsolicited. Review articles have to be contemporary and comprehensive and add information to the knowledge. Sharp critical analyses of novel data or concepts are encouraged. When relevant, a statistical analysis of data and a meta-analysis approach are recommended.

- Opinion papers, letter to the editor or comment to the editor (1500 words with $\mathbf{2}$ display items): They are submitted by invitation of the Editorial Board. They are short papers, which aim to inform scientists, industry, and the public and policymakers about cutting-edge issues in research or the impact of research. They reflect the opinion of their authors who bear full responsibility of the published paper. The references are restricted to 10 .

- Conference/Symposium papers: The journal will consider for publication the results of original work and critical reviews that are presented at conferences/symposia. Symposium organizers who wish to publish bundles of papers from a symposium/conference in IJCBR should first contact the Editor-inChief of the IJCBR (EACR@unv.tanta.edu.eg) for agreement. Supplementary material can be proposed and will be made available online. The responsibility for the preparation of a paper in a form suitable for publication lies with the author.

- Thesis: IJCBR can publish the summary and abstract of Master and PhD theses in a special issue. 
English: Good quality of written English is required. Spelling may be in British or American English but must be consistent throughout the paper. Care should be exercised in the use of biological terminology that is ill-defined or of local familiarity only. We recommend that authors have their manuscripts checked by an English language native speaker before submission.

Manuscript layout: Manuscripts should be prepared using a standard word processing program and presented in a clear readable format with easily identified sections and headings. The manuscript layout is based on the following directions.

- The main text contains Title, Abstract, Keywords, Introduction, Material and Methods, Results, Discussion, References, Tables, figures.

- The title needs to be concise and informative. Use bold, with an initial capital for the first word only and for words that ordinarily take capitals

- Short (running) title (max 80 characters including spacing).

- The article text should be typed with double-line spacing with wide margins $(2.5 \mathrm{~cm})$.

- The lines must be continuously numbered; the pages must also be numbered.

- Font Calibri 12 should be used for the text, and 12 for the tables, figure legends and references.

- The sections should typically be assembled in the following order:

- Title page contains title, authors' names, full affiliations, acknowledgements and the corresponding author's contacts and Short title.

Abstract (max 250 words, single paragraph): The abstract should be complete and understandable without citation, references, table or figure. Use structured abstract: Background, Aim, Materials \& Methods, Results and Conclusion. The context and the rationale of the study are presented succinctly to support the objectives. The experimental methods and main results are summarized but should not be overburdened by numerical values or probability values. The abstract ends with a short and clear conclusion.

Keywords: Up to five short and specific keywords should complement the title with respect to indicating the subject of the paper in alphabetic order.

Introduction: The introduction briefly outlines the context of the work, presents the current issues that the authors are addressing and the rationale to support the objectives, and clearly defines the objectives.

Material and methods: Material and methods should be described in sufficient details so that others can repeat the experiment. Reference to previously published work may be used to give methodological details, provided that said publications are readily accessible and in English. The code of ethics should be followed for all experiments use animals or human samples.

Statistical analysis of results: The statistical design and the models of statistical analysis must be described, as well as each of the statistical methods used. Sufficient statistical details must be given to allow replication of the statistical analysis. The experimental unit should be defined (e.g. individual or group of animals).

Results: Data are presented as tables and figures. Brief description of the results for each table and figure should be presented. Unpublished data can be mentioned when necessary.

Discussion: Should be separate from the Results section and should focus only on intra- and inter-data discussion (the data in the results section) as well as with the relative data in the literature. Don't repeat information already presented in the Introduction section. Start the first paragraph in the Discussion with a paragraph stating the rationale behind the study, the objectives and the main findings. End Discussion with a short conclusion.

Acknowledgements: In this section, the authors may acknowledge (briefly) their support staff.

Conflict of interest: All papers with a potential conflict of interest must include a description/explanation in a separate heading.

Funding details: The authors should state the source of findings of the study (with research funder and/or grant number). If no fund, the authors should state that the study is self-funded. 


\section{References}

Citation of references: In the text, references should be cited by the author(s) surname(s) and the year of publication (e.g. Salem, 2020). References with two authors should be cited with both surnames (e.g. Salem and Meshrif, 2021). References with three or more authors should be cited with the first author followed by et al. (in italics; e.g. Salem et al., 2021). Names of organizations used as authors (e.g. Food and Drug Administration) should be written out in full in the list of references and on the first mention in the text. Subsequent mentions may be abbreviated (e.g. FDA).

- List of references. Literature cited should be listed in alphabetical order by authors' names. It is the author's responsibility to ensure that all references are correct. All authors should be written and so the full journal name.

- References from journal articles are formatted in APA as this example: Al-Amoudi WM (2018). Toxic effects of Lambda-cyhalothrin on the rat thyroid. Involvement of oxidative stress and ameliorative effect of ginger extract. Toxicology Reports, 5: 728-736.

- References from books or official reports are formatted as this example. Kebreab E, Dijkstra ANM, Bannink A, Gerrits WJJ, \& France J (2006). Nutrient digestion and utilization in farm animals. CABI Publishing. Wallingford, UK.

- References from chapters or parts of books are formatted as this example. Nozière $P, \&$ Hoch $T$ (2006). Modelling fluxes of volatile fatty acids from rumen to portal blood. In: Nutrient digestion and utilization in farm animals (Kebreab E, Dijkstra ANM, Bannink A, Gerrits WJJ \& France J, eds.), pp. 40-47. CABI Publishing. Wallingford, UK.

Tables:

The data should be presented in tables or in graphs, not both.

- Each table should be placed on a separate page at the end of the main text.

- Tables are numbered consecutively using Arabic numbering. They are referred to as Table 1 , Table 2, etc., with capital ' $T$ ', no italics

- Each table has its explanatory caption. The caption is sufficient to permit the table to be understood without reference to the text.

- Abbreviations used in tables/figures have to be defined either as footnotes or in the caption.

Figures

- Package the figures in a single PowerPoint file. Each figure in a separate slide.

- Figure size should be readable in a width of approximately 8-175 $\mathrm{mm}$ (i.e. the maximum size of printing over two columns).

- Ensure that the font size is large enough to be readable at the final print size, use Calibri font to ensure that they are consistent throughout the figures.

- The figures should preferably be provided as TIFF or EPS files.

- The resolutions of figures must be at least $300 \mathrm{dpi}$.

- Preparation of images for a manuscript: For guidance, we refer to the Journal of Cell Biology's instructions to authors (http://jcb.rupress.org/site/misc/ifora.xhtml\#image_aquisition).

- If a cropped image is included in the main text of a paper (e.g. a few lanes of a gel), display the full original image, including the appropriate controls, the molecular size ladder and/or the scale as relevant, as a single figure in a Supplementary Material file to facilitate peer-review and for subsequent online publication.

- Supplementary material is submitted along with the main manuscript in a separate file and identified at uploading as "Supplementary File - for Online Publication Only" The title of the article is included at the top of the supplementary material.

Corresponding author's guidelines: Upon acceptance the corresponding author is required to send his/her recent formal photo to be attached to the front page of the article. 


\title{
International Journal of Cancer \& Biomedical Research
}

(IJCBR) Online ISSN 2682-2628

\author{
Editor-in-Chief \\ Mohamed Labib Salem, PhD \\ Tanta University, Egypt
}

\begin{tabular}{l} 
EACR Board \\
\hline Nehal Elmashad, MD \\
Tanta University, Egypt \\
Nabil Mohy Eldin, PhD \\
Kafrelsheikh University, Egypt \\
Doaa Al-Ghareeb, PhD \\
Alexandria University, Egypt \\
Abdel-Aziz Zidan, PhD \\
Damanhour University, Egypt
\end{tabular}

\begin{tabular}{l} 
Managing Editor \\
\hline Wesam Meshrif, PhD \\
Tanta University, Egypt \\
Sohaila Galal, PhD \\
Tanta University, Egypt \\
Production and Contact \\
\hline Hamdi Kandil \\
Tanta University, Egypt \\
Email: ljcbr100@gmail.com
\end{tabular}

\section{Advisory Board}

Alberto Montero, MD

Taussig Cancer Center, Cleveland,

USA

Yi Zhang, MD

Zhengzhou University, China

Mark Robunstein, Ph D

Medical University of South

Carolina, USA

Mohsen Farid, Ph D

Derby University, USA

Natarajan Muthusamy, Ph D

Ohio State University, USA

Hideki Kasuya, MD

Nagoya University, Japan

Sherif El-Khamisy, Ph D

Sheffield University, UK

Mohamed Ghanem, Ph D

Kafr Elshikh University, Egypt

Sayed Bakry, Ph D

Alazhar University, Egypt

Sameh Ali, Ph D

Nationa Liver Institute, Egypt

Gamal Badr, Ph D

Assuit University, Egypt

Nadia Hamdy, Pharm D

Ain Shams University, Egypt

\section{Editorial Board}

\section{Clinical studies}

Hesham Tawfik, MD

Tanta University, Egypt

Mohamed Attia, MD

Tanta University, Egypt

Mohamed Elshanshory, MD

Tanta University, Egypt

Essam Elshiekh, MD

Tanta Cancer Center, Egypt

Rasha Eraky, MD

Tanta University, Egypt

Shaima Abou-Kjatwa, MD

Tanta University, Egypt

Marcela Diaz, MD

Cleveland Clinic Foundation, USA

Mohamed Abou-El-Enein, MD

Charité Universitätsmedizin Berlin,

Germany
Alaa Eldin Almostafa, MD

McGill University, Canada

Olfat Gadallah, MD

Tanta University, Egypt

Nagla Sarhan, MD

Tanta University, Egypt

Naglaa Fathy, Pharm D

Zagazik University, Egypt

Mohamed Salama, MD

Mansoura University, Egypt

Mona Marie, MD

Alexandria University, Egypt

Preclinical studies

Mostafa El-Sheekh

Tanta University, Egypt

El-Refai Kenawy, Ph D

Tanta University, Egypt

Mohamed Noureldin, Ph D

Banaha University, Egypt

Yousry Albolkiny, Ph D

Tanta University, Egypt

Elsayed Salim, Ph D

Tanta University, Egypt

Shengdian Wang, Ph D

Chinese Academy of Sciences,

China

Sabry El Naggar, Ph D

Tnata Univesity, Egypr

Faris Alenzi, Ph D

Prince Sattam bin Abdulaziz

University, KSA

Ibrahim El-Sayed, Ph D

Menoufia University, Egypt

Tarek Aboul-Fadl, Ph D

Assiut University, Egypt

Rabab Khairat, Ph D

National Research Center,

Giza, Egypt

Wael Lotfy, Ph D

Alexandria University, Egypt

Ashraf Tabll, Ph D

National Research Center, Egypt

Nahla Shoukry, Ph D

Suez University, Egypt
Medhat Eldenary, Ph D

Tanta University, Egypt

Azza Hasan, Ph D

Menufia University, Egypt

Nanees Gamal Eldin, Ph D

Tanta University, Egypt

Mohamed Mansour, UK

Sabbah Hammoury, Ph D

Alexandria Ayadi Almostaqba

Oncology Hospital, Egypt

Nehal Aboulfotoh, Ph D

Zewail City for Science and

Technology, Cairo, Egypt

Amir Elkhami, Ph D

Galaxo, San Francisco, USA

Ahmed Alzohairy, Ph D

Zagazi University, Egypt

Wgady Khalil, Ph D

National Research Center, Egypt

Amr Amin, Ph D

United Arab Emirates

University, UAE

AbdelRahman Zekri, Ph D

National Cancer Institute, Egypt

Hussein Khamis, Ph D

Alexandria University, Egypt

Magdy Mahfouz, Ph D

Kafr Elsheikh University, Egypt

Ehab Elbedewey, Ph D

Tanta University, Egypt

Abeer Badr, Ph D

Cairo University, Egypt

Mamdooh Ghoneum, Ph D

Charles Drew University of

Medicine \& Science, USA

Haiam Abou Elela, Ph D

National Institute of Oceanography and Fisherie, Egypt

Maha EL-Demellawi, Ph D City for Scientific Research \&

Technology Applications, Egypt

Desouky Abd-El-Haleem, Ph D

City for Scientific Research \&

Technology Applications, Egypt 